\title{
The History of Urbanization in Java Island: Path to Contemporary Urbanization
}

\author{
Yustina Octifany ${ }^{1}$ \\ Received: 26 ${ }^{\text {th }}$ April 2019 Accepted: $18^{\text {th }}$ December 2019
}

\begin{abstract}
The paper presents the historical analysis of the spatial transformation and emerging urban reality in Java Island. The historical approach used to understand the urbanization dynamics from the year 1200 until the present time. The study passes through important historical events: early Archipelago, precolonial, colonial state, late colonialization, Japanese occupation, Indonesia's independence, Indonesia's democratic experiment, guided democracy, new order, fall of the new order, and post-Suharto era, in which the history of urbanization pattern is also visualized on the map. From a long time frames the colonial state, new order, and the post-1997 financial crisis are the most important influence for Java's urbanization. From the study, it reveals that the urbanization in Java Island has undergone a series of events that made the urban population contracted or expanded; hence its centers moved to different places. The study also underlines the influence of colonial and economic crises which made Java, and particularly Jakarta, to emerge as the epicenter of urbanization in Indonesia, as Jakarta's urban development was further enhanced after Indonesia's independence.
\end{abstract}

Keywords: History, Java Island, Post-Colonial, Post-Financial Crisis, Urbanization

\section{INTRODUCTION}

There are some researches that encompasses the urbanization in Java, notably in the past four decades (Firman, 2016; Firman, Kombaitan, \& Pradono, 2007). Those researches explained the condition and the drives of the mega-urbanization. The aim of this research is to analyze the urbanization in Java from a longer time frame, ranging from early Archipelago, the colonial state, new order, and present time. In order to understand the reason behind the dynamics of urbanization in Java, including the rise of the urban centers and why Java island is the most developed island in Indonesia.

Urban area in Indonesia is defined through the Law No 26 / 2007, which states that urban area is the area that has nonagricultural activity and functions as urban settlement, center and distribution of government, social, and economic services. At higher hierarchy, the same law also acknowledges metropolitan and megapolitan. In smaller units, urban and rural is defined by Government Regulation Number 37 / 1970 as the Sub-sub-district (desa or kelurahan in Indonesia) administration units that pass the threshold of the scoring system consist of several criteria's, including population density, households who engage in the agriculture sector, and accessibility towards public facilities. According to Firman (2016), urbanization as a process should be understood as a transformation from rural to urban society, implying simply as the increasing the urban population proportion over the total national population. The urbanization can happen through three methods, including rural to urban migration, reclassification of rural to urban administrative status, and birth/natural increase (Firman, 2016).

\footnotetext{
${ }^{1}$ Independent Researcher 
There are numerous theory discussing urbanization, but in 2015, there is a new urban epistemology that proposed by Brenner and Smith (2015) that disturbed current view on urban and urbanization. This new urban epistemology emerges along with the nascent urban phenomenon. This urban epistemology is divided into seven theses, including urban and urbanization is theoretical categories; urban is a process, not a universal form, settlement type, or bounded unit; urbanization involves three mutual constitutive moments: concentrated, extended, and differential urbanization; fabrics of urbanization has three dimensions, including spatial practices, territorial regulation, and everyday life; urbanization has become planetary; urbanization unfolds through variegated patterns and pathways of uneven spatial development; and the urban is the collective project in which the potential generated through urbanization are appropriated and contested.

In this paper, the urbanization in Java Island will be thoroughly explained as Indonesia has undergone a series of events. The study will focus on four important time frames: precolonialization, colonialization, Suharto era, and post the 1997 crisis. The study explains the urban form in Java, where currently Jakarta and Surabaya are dominating the urban development in Java Island. Jakarta's emergence as the important core of Java Island was influenced by Netherland colonialization and global economic depression in 1930. The urban development in Java Island has been continuing from Indonesia's Independence Era, forming mega-urbanization. The urbanization process was influenced because of capital accumulation in those urban centers. Besides capital accumulation, resource extraction also play a vital role on developing urban area. It is also found that Java is in the age of contemporary urbanization. Referring back to the seven theses, the author found the three of it from this study. That urbanization has three moments, have different pattern and pathway of uneven spatial development, and urban is a collective project.

\section{METHOD}

This study is inductive research, in which the thesis formation is explored after data collection and analysis. Focusing on the literature survey especially toward historical literature and present urban studies literature, historical approach is used to enclose the background, the motivation, the pertinent actors, and the impact on urban development. Since urbanization is the social economic changes in the society, this study also elaborates the social and economic condition that shaped urban development. To visualize the urban development, the spatial description in the form of maps is also provided.

\section{RESULT AND DISCUSSION}

\section{Precolonial Time in Java $\left(14^{\text {th }}-17^{\text {th }}\right.$ Century)}

\section{The $14^{\text {th }}$ to $15^{\text {th }}$ Century Java}

Java island was part of Indonesia archipelago, which before Dutch colonialized it, it did not have a real urban center (Van Klinken, 2009). At that time, the royal court moved constantly and surrounded by villages. The main actors in the settlement development in Java was, the Mataram Kingdom that located in South Central Java near the Brantas River became the center of economic activity and then the economic activity moved to the Kingdom of Majapahit in $14^{\text {th }}$ and $15^{\text {th }}$ century. Most of the people at that time living close to the fertile river banks for wet rice cultivation in Solo and Brantas River in Central and East Java.

\section{The $16^{\text {th }}$ to $17^{\text {th }}$ Century Java}

Java has multiple settlement center during the pre-colonial time. The trade network knit the string of mercantile urban centers situated in the kingdoms and coastal ports. In the 
same period as European in Indonesia, in the $16^{\text {th }}$ to the $17^{\text {th }}$ century, there many big and small power in Java (Ricklefs, 2001g). They classified as inland kingdom or coastal kingdom. In the inland of Java, there are two emerging kingdoms, Pajang (later known as Surakarta) and Mataram (later known as Yogyakarta which is located in Central Java). Both of these kingdoms were rich agrarian kingdoms. Even though, Mataram was an inland kingdom it authorized the coastal area, it had three roads connected to the coast of Semarang, Tegal, and Gersik urban area. Moreover, the two-big coastal power was also Surabaya (East Java) and Banten (Banten). The other was not as big, but strong and important port kingdoms, which were Demak and Jepara. All of the coast kingdoms were located in Java North Coast.

Among all of the future colonial powers, the Dutch accomplished more that Portuguese because they establish a headquarter in Jayakarta/Batavia/Jakarta, Java (Ricklefs, 2001e). Although the number of European in Batavia initially was small, the city grew rapidly as Indonesian and Chinese moved there because of the commercial prospect of Batavia (Ricklefs, 2001e). This was the emerging of Jakarta as the new urban center in Java besides other coastal cities. According to Cybriwsky \& Ford (2001), the original settlement was located near the Ciliwung River. At that time the population of the residents in 1673 was 27,068 people.

\section{Urban Intensification in Java (18th - 20th century)}

Urban intensification started when the Dutch began colonialization in Java. The colonialization can be analyzed through five processes, which are the beginning of Dutch colonialization; Compulsory cultivation (Culturestelsel); The Emergence of Liberal Politics and The Ban of Compulsory Cultivation; The Ethical Policy; Economic Liberalization in Netherland Indies 20th Century; and Economic Depression. From compulsory cultivation until economic liberalization are the era where extensive agriculture played a vital role on the urban development. The last period in economic depression time marked the turning point of the industrial emergence. In this age, urban areas intensified in Java Island notably Jakarta. The main actor of this development is the Dutch through the colonialization as explained in important time frames below.

\section{The Creation of Colonial State (1800-1830)}

The colonial state began when the Netherland Government took over the colonial land from the VOC (a trading enterprise that colonialized Indonesia) that went bankrupt in 1799 (Lindblad, 2002b; Ricklefs, 2001c). The Governor General Daendels (reigning from 1808 to 1811) set the infrastructure development that shaped the urban structure in modern Java (Dick, 2002b). Later, Daendels obliged labors to build a post road (postweg) along the north coast of Java via Priangan highlands (Dick, 2002b), or in current condition, from Anyer to Panarukan.

\section{The Compulsory Cultivation (Culturestelsel) (1830-1870)}

From 1830 to early $20^{\text {th }}$ century Dutch controlled and exploited the whole island through Compulsory cultivation (culturestelsel). The system utilized the land and labor in Java to produce cash crops in that era (sugar, coffee, tea, and more) (Dick, 2002b). The culturestelsel was not implemented outside of Java Island due to Governor General Bosch's vision to restrict their attention to Java, Sumatra, and the source of tin in Bangka (Ricklefs, 2001f). Culturestelsel influenced the economy, land development, labor mobilization, economy, transportation investment, infrastructure investment, integration to global trade, and population growth (Ricklefs, 2001c). There was also infrastructure investment including factories, storehouses, roads, bridges, irrigation, and port (Ricklefs, 2001c). In the $19^{\text {th }}$ century, besides the plantation crops and food output improvement, land communication and transportation also improves. There are four important infrastructure developments by 
Dutch, which are road, railway, telegram, telephone, and tramway (Dick, 2002b). In 1880, railway lines had been completed as the interior transportation in the north coast ports in Jakarta, Semarang, and Surabaya; and in 1890 the network has become linked network in whole Java. The legacy from culturestelsel was the capital investment that flowed and concentrated in Java Island, that laid the trigger for urbanization in Java.

In fact, throughout the $19^{\text {th }}$ century, the population in Java maintained a steady increase that had begun in the the $18^{\text {th }}$ century (Ricklefs, 2001c). The end of $18^{\text {th }}$ century, the population was about 5 million and by 1890 it reached 23.6 million. The number of populations which made the culturestelsel achieved a greater success eventually. Despite the administrative and economic development by the Dutch colonial government (Christie, 1991), there was not much urban developments in 1815, because the agriculture did not need agglomeration of the population to support its activities. However, Jakarta had a different effect, as the center of colonial system Jakarta became the administer center of seizure of agricultural surpluses from culturestelsel (Winarso, 2011). According to Winarso (2011) William Daendels, in 1808 also ordered the development of the residential area in the suburban Jakarta make the attempt to widen the area of Jakarta. At the end of 1811, Batavia's population consist of 2,007 Europeans and 45,000 Asians.

\section{The Emergence of Liberal Politics and The Ban of Compulsory Cultivation (1880-1900)}

With the rise of liberal politics in Netherland, the colonial government ruled the economic activity with liberal economic perspective in which government acts as regulator and promoter private enterprises in colony business (Ricklefs, 2001c). With the opening of the Suez Canals in 1869, it increased the relation between Indonesia and foreigners and private enterprises in Netherland Indies. Before the Agrarian Law in 1860, the private export was equal to colonial government export and by 1885 the private export was ten times to government export. The liberal period (1870-1900) was a period where the exploitation intensified in Indonesia, both in Java and in other islands.

\section{The Ethical Policy (1900-1920)}

The ethical policy was the redemption from the colony to the colonialized land. It aimed for the increase in health, education, public works, and welfare in Java (Dick, 2002b). Moreover, the liberal economic policy (1870-1900) saw Java as a potential market, which required an improvement in living standards (Ricklefs, 2001a). In summary, the ethical policy brought a wider spectrum of the development program to Java. However, in urbanization perspective, the ethical policy was only established in Java hence most of the public and private development, either physical (infrastructure and agriculture intensification) and non-physical development (health, governance, and education), most were built in Java, notably in the western part of the island.

\section{Economic Liberalization in Netherland Indies (1920-1930)}

In 1920, the economic structure changed as the manufacturing sector and the oil industry emerged in outer islands (Ricklefs, 2001a; Dick, 2002b). Java plantation economy was no longer the powerhouse of the Netherland Indies (Dick, 2002b). Hence, the economic structure change from agriculture to small scale and manufacturing industry. This revolutionized the transport, communication, sugar milling industry, irrigation, metalworking, heavy engineering industry, consumer goods (bread, soft drink, and ice), construction material (brick and timber), and public utilities (gas and power). These goods were beneficial because the land in Java became scarcer and labor more abundant (Dick, 2002b).

In the Netherland Indies, Jakarta had more subsequent urban development (Cybriwsky \& Ford, 2001). According to Cybriwsky \& Ford (2001), after the Tanjung Priok 
built in 1877 and 1886, the traffic to Batavia was increasing after the Suez Canal in 1869. They also mentioned that Tanjung Priok now emerged as a new deep-sea port and had important facilities including dry dock, warehouse, waterfront industries, and many more. It was also followed by an export boom and foreign investment in Java and the outer islands in the first two decades. The private investment in the Netherland Indies also rose in the early $20^{\text {th }}$ century from $\$ 300$ million in 1900 to $\$ 675$ million in 1914 and peaked to 1.6 billion in 1930 .

\section{Depression (1930-1942)}

The turning point for urban development in the western part of Java Island was the economic depression in the 1930s, which lead the industrial development to western region in Java as the direction of urban center in Indonesia. The postwar boom followed by world recession in 1921-1922 (Lindblad, 2002a). It was when the export value started to collapsed (Lindblad, 2002a). Java was particularly affected by the falling price of its commodity, sugar (Lindblad, 2002a; Ricklefs, 2001e). In 1930, 52\% of the product was sold to the industrialized country in North America and Europe, the center of crisis (Ricklefs, 2001a). Because of the crisis, the price for all Netherland Indies (NI) main export fell. The situation got worse when Japanese devalued their yen in December 1931, their import penetrated Indonesia and dominated the local market (Ricklefs, 2001d). The economic depression destroyed export price, government revenue, expenditure, and welfare (Dick, 2002b). After the depression, the government restructureed the economic activity in Java (Dick, 2002a), they start to consider a more inward-looking trade of import substitution and industrialization, abandoned free trade, restricted Japan import, developed cheap labor to produce manufacturing in competition with Japan. This mark the industrialization of Java right after the economic depression.

The government had already taken measures in developing small-scale industries beforehand (Dick, 2002a). For example, the textile institute in Bandung (1919-1926), Handloom fabric near Surabaya, paint and soap manufacturer in East Java. Foreign investor established new industries in Jakarta, including automobiles (General motor), rubber tires (Goodyear), margarine (Unilever), shoes (Bata), batteries, and biscuits. The industrial center of gravity, therefore, shifted west, especially for consumer goods industries (Dick, 2002a). The industry was import substitution industries that invested by Dutch, America, and Japanese Ventures. The late colonial industrialization brought GDP jump from $8 \%$ to $12 \%$ in 1931-1939. The industry continued to grow. In late 1930, the project included light bulbs, bicycles, glycerin, vehicle assembly, confectionery, metal fitting, rubber sandals, coconut oil, and soaps. In 1938, the Netherland Indies was almost self-sufficient in most products. The industrial development was most rapid in Western Java triggered by the economic depression (Dick, 2002a).

\section{The Role of Timber Extraction for Urban Development under colonialization}

The capital investment and accumulation due to extensive agriculture and industrial development are not the only main players of Javas urban development. Java Island's resource extraction also drained to fuel urban development. From forest extraction history, Peluso (1991) mentioned the teak exploitation role in developing the island. Teak exploitation began in 1651 in Jepara between VOC and the susuhunan of Mataram for initially ship material. During the culturstelsel, the teak forest was logged heavily to build the sugar factories, coffee warehouses, tobacco drying sheds, and housing for the extensive government plantation (Peluso, 1991). The author also mentioned other timber exploitation to build tobacco drying sheds in Semarang and the firewoods were extracted to fuel sugar refining factories. On the era of liberal politics, the Java's forest continued to be exploited to build the railway for transportation between East and West Java by 1894 (Peluso, 1991) 
through Batavia, Bandung, Yogyakarta, and Surabaya. The teak is used to build the railway sleepers and fuel the locomotives. The railway building continues to be developed even until the ethical policy era in, 1910, reached almost every district on the island. By the time the colonial regime end, Peluso mentioned that the timber from Java's forest was drained for roads, railways, and export. This extraction left us with the development of future urban centers on Java island and the transportation legacy that continues until the present time.

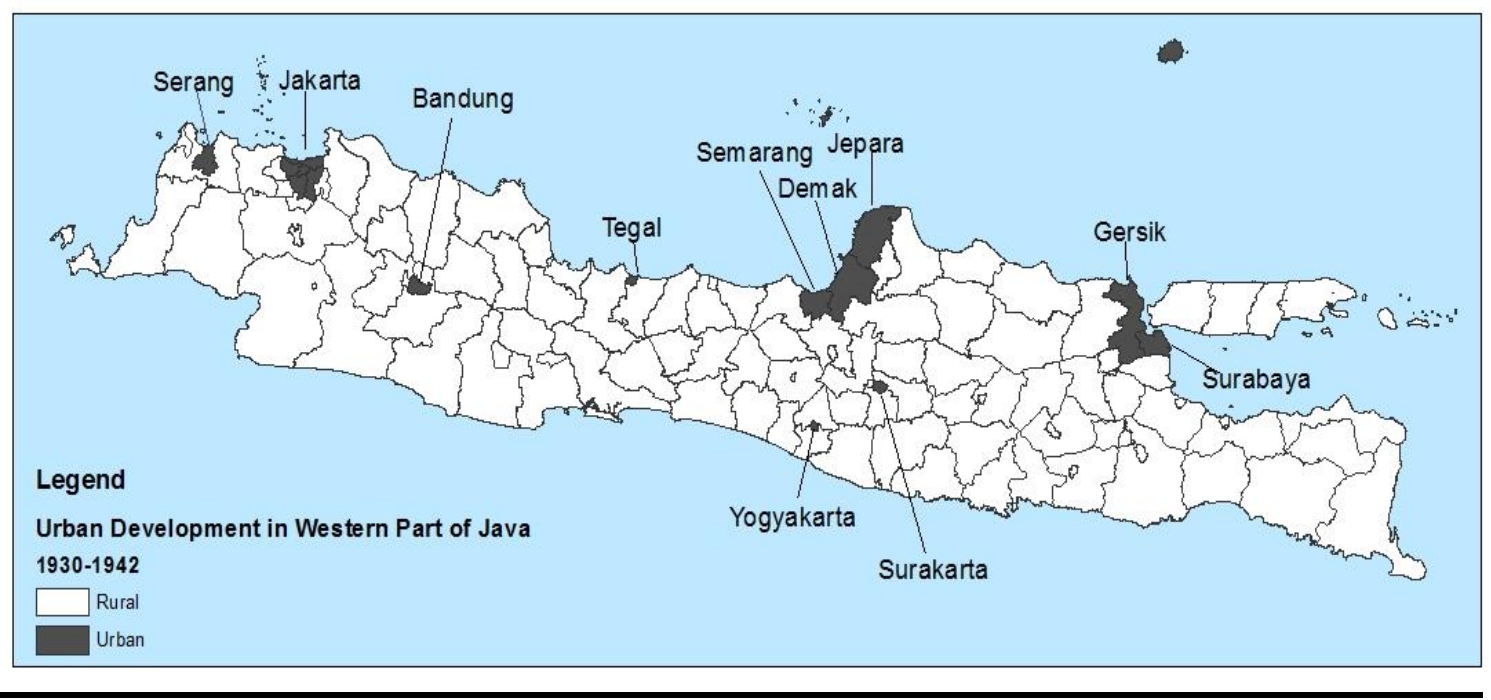

Figure 1. Urban Development in Western Part of Java

\section{Stagnation of Urban Development (1942-1965)}

During the Japanese intervention, revolution, independence, and guided democracy, there was not much urban development in Java. The country was filled with political and economic instability; and the wars in this time frame was creating a lot of collateral damage to urban infrastructure and physical landscape (Dick, 2002a). The economic policy of Indonesian governance in the Sukarno era was nationalized a lot of Netherland Indies asset such as post, rail, bank, and trading companies also the government move the (Dick, 2002a). From independence and guided democracy era, the foreign and domestic investment had decreased because of Soekarno's anti-capitalist policies (Winarso, 2011), hence the capital to build Java island won't be as much as in Soeharto era's onward.

In 1964, Milone (1964) studied Indonesia's urbanization. Milone said that Indonesia had a balanced urban growth than many other Southeast Asia countries because it was not dependent towards the heavy manufacture industrialization hence urbanization in Indonesia was dominated by small town rather than the big town. The study explained two reasons why the small town was survived in that era. The first reason was because of the distributed administration levels to the society from the governor, resident, bupati, wedana, camat, to lurah. The administration center was accessible by transportation nodes and public infrastructure. The second reason was the entrepreneurial function of small tows as the center of agriculture and plantation, including small processing industry, market, and distribution town, and more.

In that time, there were 19 municipalities in Java with a population above 50,000 inhabitants meanwhile in the outside Java there were 29 municipalities over 50,000 inhabitants and 11 municipalities less than 50,000. Java's largest cities in 1961 were Jakarta, Surabaya, Bandung, Semarang, Surakarta, Malang, Yogyakarta, Kediri, Cirebon, Bogor, Tasikmalaya, Madiun, and Pekalongan. The newly established inland cities were Bandung 
and Malang which grow faster than the $17^{\text {th }}$ and $18^{\text {th }}$ century port cities, Cirebon, Pekalongan, and Semarang. Jakarta according to Milone (1964) was a center for major economic, political, administrative, higher education, and technical function which was not a primate city. Meanwhile, Surabaya was a major port for export-import, industry, and naval station. Moreover, Bandung functioned as a major transportation, communication, higher education center, and industrial enterprises. Back then in 1964, the governance rule distributed to Bogor for agriculture. The load of the nation was distributed to several cities in Java. At that moment, Jakarta was only the center of administration. The strategic activities were distributed to Bogor, Bandung, and Yogyakarta. The degree of urbanization on Java Island was only $16.05 \%$ at the 1960 s. Malone also stated that the urban development in Java at this moment was slower than the outer islands, which became the earner region for Indonesia. Even faced with economic stagnation, there were new urban areas developed including Bogor, Cirebon, Tasikmalaya, Pekalongan, Malang, Kediri, and Madiun.

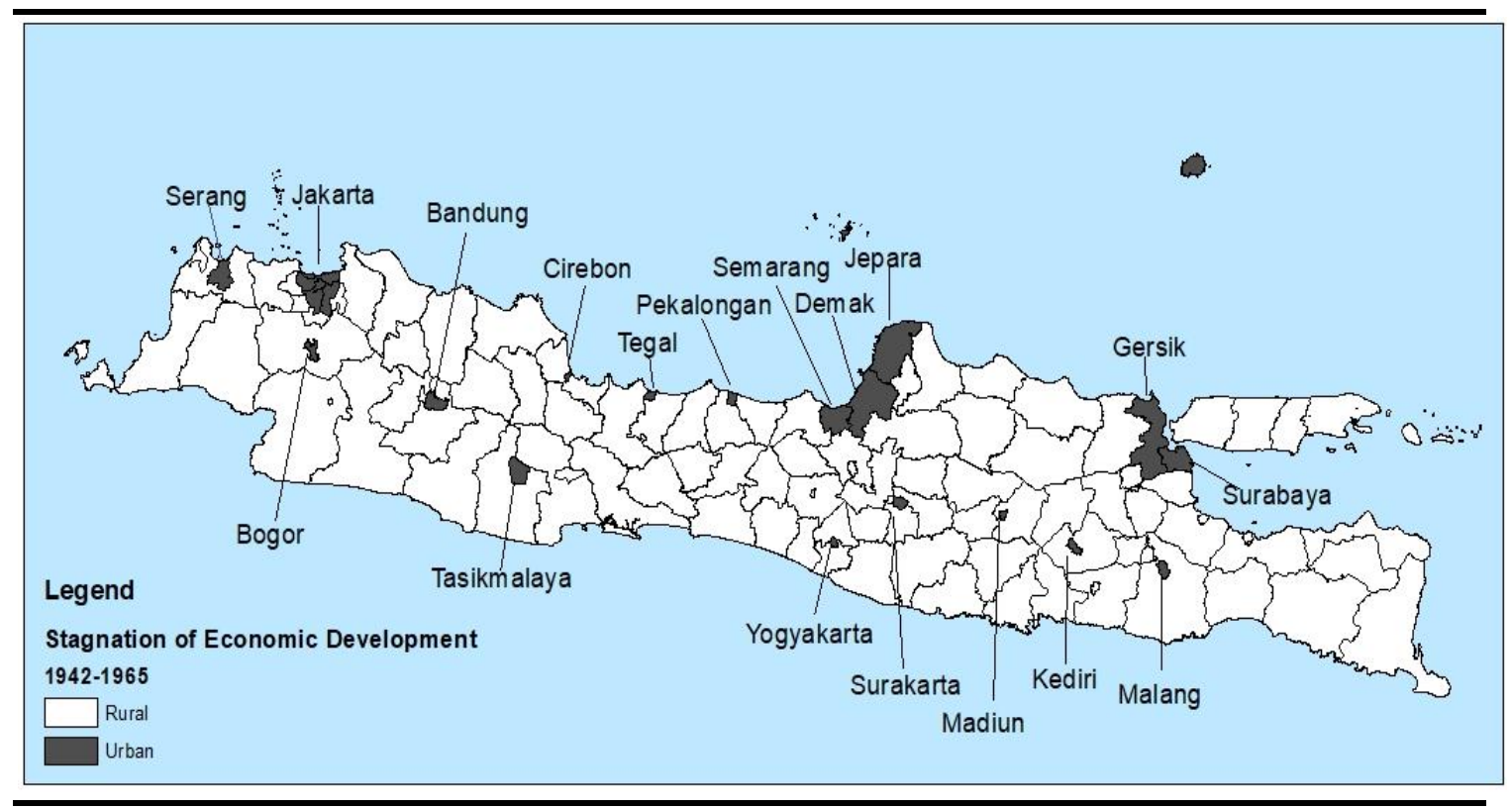

Figure 2. Stagnation of Economic Development 1942-1965

\section{Urbanization in Liberal Economy Era: Formation of Large Urban Concentrations (1965-1998)}

The liberal economy era in Indonesia was started when Suharto took over the office in 1966. Indonesia began the centralized, authoritarian, liberal economy nation. According to Wie (2000), there are three economic changes during the Suharto era. First, the era of stabilization, rehabilitation, partial liberalization and economic recovery (1966-1973). This stage Indonesia economic was integrated into the global economy and built upon foreign aid, foreign direct investment, and the private sector. However, the economy was inward-looking and protected by the government. Second, the era of oil booms, rapid economic growth and increasing government intervention (1974-1982). This stage marked the oil and timber exploitation that yielding high oil revenue. Indonesian government could develop numerous public infrastructures because of high oil revenue including roads, railways, bridges, harbors, airports, and telecommunication; and government-initiated import substitution industry, upstream industry, and high-tech industry. Most of the industry are large scale, upstream basic, resource procession, and state-owned. In Java, the large industry emerged in some urban area such as Jakarta, Surabaya, and lesser extent to Bandung. The other industrial complex also emerged in Cilegon and Cilacap (Wie, 2000). According to Wie, the development program, mostly manufacturing sector was believed as the reason for rapid 
urbanization in those areas. Therefore, by 1990, Jakarta's population reached 8.3 million and Bandung, Surabaya, and Semarang had more than one million inhabitants. Third, the era of Post-Oil Boom, Deregulation, Renewed Liberalization and Rapid Export-Led Growth (1983-1996). The third stage starting after the fall of oil price. The government imposed the export-oriented industry instead of import-substitution industry and the government liberalized the market by opening up the market for the foreign investors. The urban development programs were funded by both domestic and foreign investment (Hudalah \& Firman, 2012; Winarso, 2011).

The impact of urbanization from the liberal economic policy was big, including the creation of a big metropolitan area, activation of fringe area, the formation of the urban belt, and the stagnation of small to medium town. First, in the 1960s the regional planner recognized the existence of extended urbanization in Jakarta, Bogor, Tangerang, and Bekasi (Jakarta Metropolitan Area/JMA). The national economic activity was centralized in Jabodetabek during the Suharto era, in which $60 \%$ of economic activities were centered in Jakarta (Firman, 2003). JMA turned into a new central business district with high rise building, financial services center, and hubs for the market, decision-makers, and skilled workers and entrepreneur - made JMA the most attractive domestic and foreign investment (Bunnell \& Ann Miller, 2011). The foreign direct investment opened up new manufacturing, finance, and retail business producing a new economic transformation, though they are hinged upon the manufacturing sector (Firman, 2017; Firman et al., 2007).

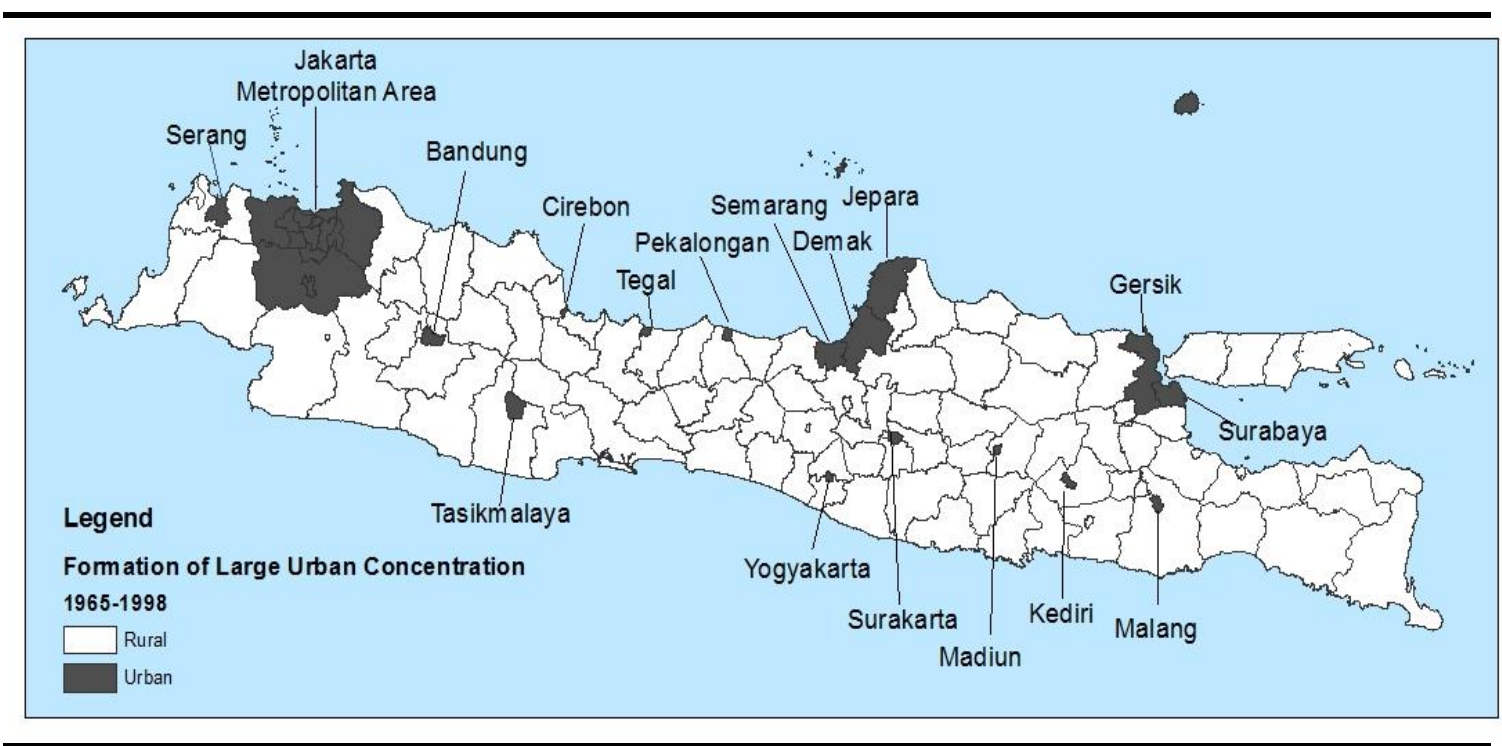

Figure 3. Firmation of Large Urban Concetration

Second, the late Suharto era in the 1990s left an important mark on spatial transformation in Indonesia's metropolitan by supporting the development of a fringe area of the metropolitan (Firman et al., 2007). There was the internal migration of Indonesians to Java's metropolitan fringe area. Two activities developed in the fringe area were real estate boom--suburban housing and new towns development (Winarso \& Firman, 2002)--and industrial estates (Hudalah \& Firman, 2012). The development of fringe area caused the visible feature in Jakarta and many export-oriented industrial districts in the suburban area, which was branded as the prime features of New Order regime (Cybriwsky \& Ford, 2001). Third, the spatial development in Java also tends to form urban belts that connect the large cities, including Jakarta-Bandung, Cirebon-Semarang, Yogyakarta-Semarang, and Surabaya-Malang (Firman, 2003). Fourth, it is indicated that that the small and medium town in Java experienced stagnant in development or became the pension town (Firman, 
2003). Because of the centralized economy in Java, the urbanization level increased from $25.1 \%$ in 1980 to $35.7 \%$ in 1990 , resulting in the population of Jabodetabek reached more than 11 million by the end of 1990 (Firman et al., 2007).

\section{Post-Crisis Mega Urbanization (1998 - present)}

After the financial crisis in 1998, Indonesia recovered quite fast (Aswicahyono, Hill, Narjoko, \& others, 2013). There was a transition to the democratic and decentralized government in 2001. Although the manufacturing sector was recovered after the financial crisis, manufacturing was no longer the growth engine in Indonesia (Aswicahyono et al., 2013). Nevertheless, Java still dominates Indonesia's economy and population (Aswicahyono et al., 2013; Hill, Resosudarmo, Vidyattama, \& others, 2009). It is also proven by the recent data, that up until 2010, Java's urban population grew tremendously post-crisis from 58.9 to 80 million during the 2000 to 2010 period (Firman, 2017).

In period 2000-2010, Java, as argued by Firman (2017), has changed into a mega urbanization stage, in which the features of the mega-urbanization are first, the creation of Mega-Urban Region In Jakarta and Surabaya, and soon it will be followed by Bandung; second, the in situ urbanization means that the rural units now are able to change into urban units; third, Jakarta and Bandung Mega-Urban Region has started to form into one unit; fourth, the employment structure changes from manufacture to service sector in core city and the domination of manufacturing sector for employment in suburban; and lastly, the slow growth of medium and small-sized town. Among all the features, there is the continuation of preexisting condition before the 1997 crisis with a bigger magnitude. The emerging figure after the financial crisis in 1998 is the mega urbanization. By 2010, there were 12 cities that have more than one million inhabitants in Java, including Jakarta, Surabaya, Semarang, Bandung, Tangerang, South Tangerang, Bekasi, Bogor and Depok (Firman, 2017). Among these major cities, there are three that dominating the urban development in Java, which are Jakarta, Surabaya, and followed by Bandung. The mega-urbanization also has a characteristic called "the metropolitan turnaround" (Firman, 2017). It happens when the population growth in the core city area decelerates and the population in the outskirts grows much faster, notably in the metropolitan areas including Jakarta, Bandung, Surabaya, Yogyakarta, and less in Semarang (Firman, 2017).

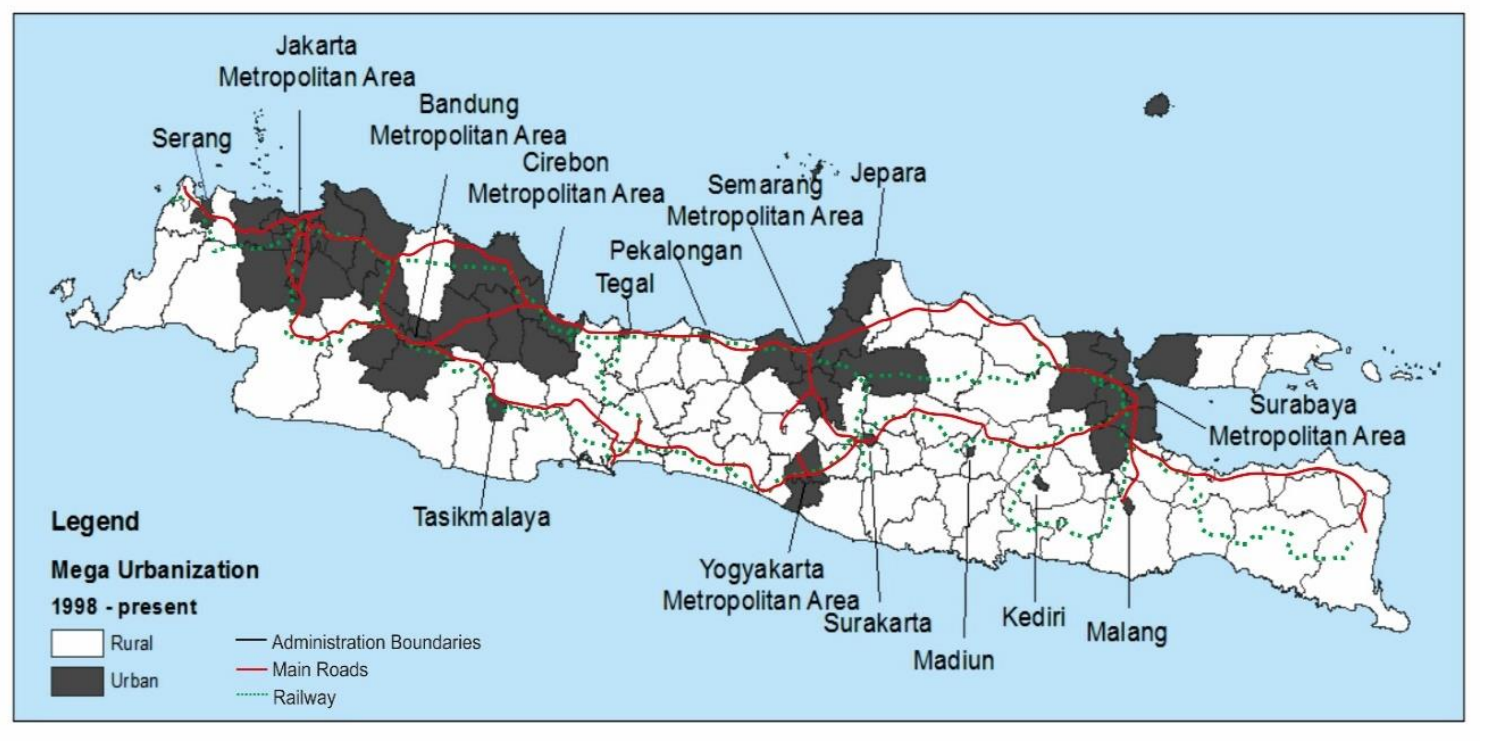

Figure 4. Mega Urbanization 1998-Present 


\section{CONCLUSION}

From the long historical period, there are three important urban episodes for urban development in Java, which are colonialization in which urban intensification took place; Suharto era which resulted in large urban areas, and the post 1998 financial crisis which promotes mega urbanization. After the fall of Suharto, the large urban areas change into a mega-urbanization type when the pattern of urbanization is polycentric, has extremely large scale, characterized as uneven development, and starts to form the urban interaction among the centers. The mutual reason behind the urban development is the accumulation of capital-both domestic and foreign investment--that cycles only in Java island throughout the colonial, Suharto, and Post Crisis times--notably on the emergence of the western part of the island as the center after 1930s economic depression and 1998 financial crisis. Besides capital accumulation, resource extraction also contributed to driving urbanization.

The urbanization in Java island has a more elaborate character rather than just natural growth, migration, urban reclassification, density, access to public service, and household employment sector. Java Island is obviously in the age of contemporary urbanization when the urban area can be concentrated and extended and has a different pattern and pathway that shaped uneven urban fabrics. The concentrated, expansion, and uneven urban fabrics are shaped by the capital accumulation in that particular area. For now, the capital is central to the metropolitan and megapolitan areas and the suburban of the metropolitan area. In fact, urban development nowadays is more centralized toward metropolitan suburban areas. Firman (2002) mentioned that resource-rich regions such as East Kalimantan and Papua could potentially develop faster as long as the local government and the community have the capacity to implement urban development programs. However, up until now these resourcerich provinces and municipals/districts could not keep up with the urban development that supported by the capital accumulation compared to that of in metropolitan centers in Java.

The findings indicate that the political and social struggle in Java Island potentially plays a bigger role in urban development, apart from the natural resource or capital investment accumulation. This leads to the seventh thesis, which states that the urban is a collective project - the potentials generated through urbanization are appropriated and contested. The contestation, appropriation, and struggle in Java--notably the mega-urban center--is the reason why the capital accumulates in those areas regardless the natural resource availability. There is numerous struggle that made Java Island and Jakarta particularly are the gravity of Indonesia, in which the capital is accumulated. Jakarta has become the center of economy and governance, thus became the center of urbanization in Indonesia. This is the initial idea that emerges from the remarks on contemporary urbanization towards the historical information of Java urbanization. In future research, there should be more researches that focus on the effect of political struggle potentially to be the roots of capital accumulation that forms the urbanization.

Learning for Java Island, a historical study would have a meaningful understanding of urban development, apart from the demographic and economic calculation. The example of the role of economic depression in turning the urban centers of Java or political struggle and capital accumulation making Java the most developed urban area in the Indonesia are the roots of regional disparity between Java and outer islands in Indonesia. Therefore, if Indonesian government wants to address the regional disparity within Indonesia, they could begin by redistributing accumulated capital and slowing down the urban metabolic desire of Java's metropolitans.

\section{ACKNOWLEDGEMENT}

The earlier version was presented at Research and Development Congress on Sustainable Urbanization in the Course of ASEAN Economic Integration on June 26-30 ${ }^{\text {th }}$, 2017 in Manila, Philippines. 


\section{REFERENCES}

Aswicahyono, H., Hill, H., Narjoko, D., \& others. (2013). Indonesian industrialization: a latecomer adjusting to crises. Pathways to Industrialization in the Twenty-First Century: New Challenges and Emerging Paradigms, 193.

Brenner, N., \& Schmid, C. (2015). Towards a new epistemology of the urban? City, 19(2-3), 151-182. https://doi.org/10.1080/13604813.2015.1014712

Bunnell, T., \& Ann Miller, M. (2011). Jakarta in post-Suharto Indonesia: decentralisation, neo-liberalism and global city aspiration. Space and Polity, 15(1), 35-48.

Christie, J. W. (1991). States without cities: Demographic trends in early Java. Indonesia, (52), 23-40.

Cybriwsky, R., \& Ford, L. R. (2001). City profile: Jakarta. Cities, 18(3), 199-210.

Dick, H. W. (2002a). Formation of the nation-state, 1930s-1966. In The emergence of a national economy: An economic history of Indonesia (Vol. 2000, pp. 153-193).

Dick, H. W. (2002b). State, nation-state and national economy. In The emergence of a national economy: An economic history of Indonesia (pp. 9-34).

Firman, T. (2002). Urban development in Indonesia, 1990-2001: from the boom to the early reform era through the crisis. Habitat International, 26(2), 229-249.

Firman, T. (2003). The spatial pattern of population growth in Java, 1990-2000: Continuity and change in extended metropolitan region formation. International Development Planning Review, 25(1), 53-66.

Firman, T. (2016). Demographic Patterns of Indonesia's Urbanization, 2000-2010: Continuity and Change at the Macro Level. In Contemporary demographic transformations in China, India and Indonesia (pp. 255-269). Retrieved from http://link.springer.com/chapter/10.1007/978-3-319-24783-0_16

Firman, T. (2017). The urbanisation of Java, 2000-2010: towards 'the island of mega-urban regions.' Asian Population Studies, 13(1), 50-66. https://doi.org/10.1080/17441730.2016.1247587

Firman, T., Kombaitan, B., \& Pradono, P. (2007). The dynamics of Indonesia's urbanisation, 1980-2006. Urban Policy and Research, 25(4), 433-454.

Government of Indonesia. Government Regulation No 37 year 1970 about Government Investment for PT. Krakatau Steel Establishment. , 37 § (1970).

Government of Indonesia. Law No 26 year 2007 on Spatial Planning. , Pub. L. No. 26 (2007).

Hill, H., Resosudarmo, B. P., Vidyattama, Y., \& others. (2009). Economic geography of Indonesia: location, connectivity, and resources. In Reshaping economic geography in East Asia (p. 115). Retrieved from http://elibrary.worldbank.org/doi/pdf/10.1596/978-0-8213-7641-6\#page=148

Hudalah, D., \& Firman, T. (2012). Beyond property: Industrial estates and post-suburban transformation in Jakarta Metropolitan Region. Cities, 29(1), 40-48.

Lindblad, J. T. (2002a). The late colonial state and economic expansion, 1900-1930s. In The emergence of a national economy: An economic history of Indonesia (pp. 111-152).

Lindblad, J. T. (2002b). The outer islands in the 19th century: Contest for the periphery. In The Emergence of a National Economy: An Economic History of Indonesia, 1800-2000 (pp. 82-110).

Milone, P. D. (1964). Contemporary urbanization in Indonesia. Asian Survey, 4(8), 1000-1012.

Peluso, N. L. (1991). The history of state forest management in colonial Java. Forest \& Conservation History, 35(2), 65-75.

Ricklefs, M. C. (2001a). A New Colonial Age. In A History of Modern Indonesia since c. 1300 (pp. 193-205). Retrieved from http://link.springer.com/chapter/10.1007/978-1-349-22700-6_13

Ricklefs, M. C. (2001b). Java, 1792-1830. In A History of Modern Indonesia (pp. 143-154). Retrieved from http://link.springer.com/chapter/10.1007/978-1-349-16645-9_10

Ricklefs, M. C. (2001c). Java, 1830-1900. In A History of Modern Indonesia since c. 1300 (pp. 155-170). Retrieved from http://link.springer.com/chapter/10.1007/978-1-349-22700-6_11

Ricklefs, M. C. (2001d). Repression and Economic Crisis, 1927-42. In A History of Modern Indonesia since c. 1300 (pp. 227-245). Retrieved from http://link.springer.com/chapter/10.1007/978-1-349-22700-6_15

Ricklefs, M. C. (2001e). The Arrival of the Europeans in Indonesia, c. 1509-1620. In Third Edition. A History of Modern Indonesia since c. 1200 (pp. 25-35). Retrieved from http://link.springer.com/chapter/10.1007/9781-349-22700-6_3

Ricklefs, M. C. (2001f). The Outer Islands, c. 1800-1910. In A History of Modern Indonesia since c. 1300 (pp. 171191). Retrieved from http://link.springer.com/chapter/10.1007/978-1-349-22700-6_12

Ricklefs, M. C. (2001g). The Rise of New States, c. 1500-1650. In Third Edition. A History of Modern Indonesia since c. 1200 (pp. 36-59). Retrieved from http://link.springer.com/chapter/10.1007/978-1-349-16645-9_4

Van Klinken, G. (2009). Decolonization and the making of middle Indonesia. Urban Geography, 30(8), 879-897. 
Wie, T. K. (2000). The Soeharto era and after: stability, development and crisis, 1966-2000. The Emergence of a National Economy: An Economic History of Indonesia, 2000, 194-243.

Winarso, H. (2011). Urban dualism in the Jakarta metropolitan area. In Megacities (pp. 163-191). Retrieved from http://link.springer.com/chapter/10.1007/978-4-431-99267-7_8

Winarso, H., \& Firman, T. (2002). Residential land development in Jabotabek, Indonesia: triggering economic crisis? Habitat International, 26(4), 487-506. 